\title{
HUBUNGAN KEKERABATAN BAHASA BALI DAN SASAK DALAM EKOLEKSIKON KENYIURAN: ANALISIS LINGUISTIK HISTORIS KOMPARATIF
}

\author{
Oleh \\ Luh Gde Inten Purnama Sari Setiawan \\ Triton Denpasar \\ Email: girlsactive88@gmail.com
}

\begin{abstract}
Abstrak
Analisis linguistik historis komparatif merupakan sebuah pendekatan dalam mengetahui hubungan kekerabatan antara satu bahasa dengan bahasa lainnya. Pendekatan analisis ini bertujuan untuk mengetehaui seberapa dekat satu bahasa dengan bahasa yang dibandingkan. Penelitian ini menggunakan data dalam bentuk leksikon-leksikon bahasa Bali dan bahasa Sasak yang berhubungan dengan pohon kelapa. Penelitian ini merupakan penelitian deskriptif kualitatif dengan menggunakan teknik wawancara dalam pemerolehan datanya. Hasil dari penelitian ini menunjukkan bahwa Bali dan Sasak (NTB) tidak hanya secara geografis berdekatan, tetapi kedua bahasanya juga berkerabat satu dengan lainnya. Hal ini dibuktikan dari adanya kesamaan perbendaharaan kata dalam ruang lingkup ekoleksikon kenyiuran. Dengan menggunakan teori Leksikostatistik, bahasa Bali dan bahasa Sasak termasuk dalam kategori language of family
\end{abstract}

\section{Kata Kunci: LHK, Kenyiuran, Bahasa Bali \& Bahasa Sasak}

\section{PENDAHULUAN}

Kajian atas perkembangan dan perbandingan antara bahasa-bahasa adalah salah satu kajian linguistik. Dalam studi bahasa sekarang, bidang kajian ini disebut linguistik historis komparatif (Suparno, 2013:28). Dari labelnya tampak bidang ini berhubungan dengan sejarah, perkembang-an, dan perbandingan antara bahasa-bahasa. Sementara itu, Keraf (1984:22) mengatakan bahwa linguistik bandingan historis (linguistik historis komparatif) adalah suatu cabang dari Ilmu Bahasa yang mempersoalkan bahasa dalam bidang waktu serta perubahan-perubahan unsur bahasa yang terjadi dalam bidang waktu tersebut. Adapun salah satu tujuan dan kepentingan linguistik historis komparatif adalah mengadakan pengelompokkan (subgrouping) bahasa-bahasa dalam suatu rumpun bahasa. Bahasa-bahasa dalam suatu rumpun yang sama belum tentu sama tingkat kekerabatannya atau sama tingkat kemiripannya satu sama lain.

Dalam kajian bahasa secara diakronik dinyatakan bahwa bahasa-bahasa yang kita kenal pada masa ini merupakan suatu fosil artinya merupakan hasil peninggalan masa purba karena setiap kata memiliki sejarahnya sendiri. Kosa kata yang digunakan oleh penutur bahasa pada saat ini merupakan cerminan (refleksi) bentuk masa silam karena setiap perkataan itu selalu diturunkan dari generasi ke generasi berikutnya. Para ahli bahasa memprediksikan bahwa dalam waktu 1000 tahun, terdapat sekitar $20 \%$ terjadinya perubahan atau kepupusan kosa kata suatu bahasa. Dari sekian banyak kosa kata yang berubah atau pupus tersebut terdapat kosa kata yang jarang berubah karena frekuensi penggunaannya dalam kehidupan sehari-hari sangat tinggi sehingga kosa kata tersebut relatif kalis (kebal) terhadap perubahan. Kosa kata tersebut meliputi: nama-nama tubuh badan, bilangan (numeral), alam sekitar yang umum dan lain sebagainya.

Bahasa Bali dan Bahasa Sasak adalah dua bahasa yang tergolong dalam keluarga Bahasa Austronesia yang dituturkan oleh masyarakat khusunya di bagian Tengah Indonesia yaitu Pulau Bali dan Nusa Tenggara Barat. Bahasa Bali adalah sebuah bahasa Austronesia dari cabang Sundik dan lebih 
spesifik dari anak cabang Bali-Sasak. Bahasa ini terutama dipertuturkan di pulau Bali, pulau Lombok bagian barat, dan sedikit di ujung timur pulau Jawa. Dari penelusuran sejarah dan antropologi dikemukakan bahwa meskipun masyarakat Suku Bali dan Suku Sasak merupakan dua etnis yang tinggal di dua kawasan yang secara geografis berbeda, namun keduanya memiliki persamaan dalam penggunaan bahasa sebagai alat komunikasi. Sehingga dapat dikatakan kedua bahasa tersebut mempunyai hubungan kekerabatan bahasa yang dekat.

Sesuai dengan pemaparan di atas, maka artikel ini akan membahas kekerabatan antara bahasa Bali dan bahasa Sasak dalam konteks ekoleksikon yang berhubungan dengan kelapa. Kelapa disebut sebagai pohon kehidupan yang menyediakan seluruh kebutuhan hidup manusia. Tanaman kelapa dikenal sebagai pohon yang mempunyai banyak kegunaan, mulai dari akar sampai pada ujungnya (daun), dari produk non-kuliner maupun kuliner, dan juga produk industri sampai produk obatobatan. Kelapa umumnya ditemukan di daerah tropis seperti Indonesia. Berkatan dengan letak geografisnya, Baik di Bali maupun di Nusa Tenggara Barat dapat banyak sekali dijumpai pohon kelapa ini. Selain itu, berkaitan dengan melihat kekerabatan kedua bahasa ini maka akan digunakan leksikon dengan konteks lainnya seperti penyebutan hitungan jumlah. Sehingga artikel ini akan dapat mengidentifikasi kekerabatan antara Bahasa Bali dan Sasak dalam ruang lingkup ekoleksikon kenyiuran dan penyebutan jumlah.

\section{METODE PENELITIAN}

Data yang digunakan dalam artikel ini adalah ekoleksikon kenyiuran dan data tambahan yang berupa bilangan angka dari angk 1-25, lalu angka 100, dan 150. Data terkait ekoleksikon kenyiuran pada bahasa Bali dan Sasak dikumpulkan dengan menggunakan metode pengamatan langsung di lapangan atau metode simak. Metode ini memiliki teknik dasar yang berwujud teknik sadap. Sementara itu, teknik pengumpulan data yang digunakan adalah teknik wawancara terhadap informaninforman yang merupakan penutur bahasa Bali dan penutur bahasa Sasak dan teknik pencatatan. Penelitian ini menggunakan metode kualitatif dan kuantitaif. Mahsun (2005:198) mengatakan bahwa metode kualitatif dimaksud sebagai cara pengelompokkan bahasa turunan ke dalam suatu kelompok yang lebih dekat hubungannya, karena memperlihatkan inovasi yang berciri linguistik eksklusif yang menyebar pada bahasa-bahasa yang diperbandingkan. Kemudian teknik yang digunakan dalam menganalisis data yaitu teknik leksikostatistik.

\section{Teori Leksikostatistik}

Keraf (1984:34) mengatakan bahwa bahasa-bahasa kerabat yang berasal dari proto yang sama selalu akan memperlihatkan kesamaan-kesamaan berikut:

(1) kesamaan sistem bunyi (fonetik) dan susunan bunyi (fonologis);

(2) kesamaan morfologis, yaitu kesamaan dalam bentuk kata dan kesamaan dalam bentuk gramatikal;

(3) kesamaan sintaksis, yaitu kesamaan relasinya antara kata-kata dalam sebuah kalimat.

Dalam membandingkan dua bahasa atau lebih dapat menggunakan teknik leksikostatistik. Keraf (1984:121) mengatakan bahwa leksikostatistik adalah suatu teknik dalam pengelompokan bahasa yang lebih cenderung mengutamakan peneropongan katakata (leksikon) secara statistik, untuk kemudian berusaha menetapkan pengelompokkan itu berdasarkan persentase kesamaan dan perbedaan suatu bahasa dengan bahasa lain.

Keraf (1984:128) menyatakan bahwa sebuah pasangan kata akan dinyatakan kerabat bila memenuhi salah satu ketentuan (a) pasangan itu identik, (b) pasangan itu memiliki korespondensi fonemis, (c) kemiripan secara fonetis, atau (d) satu fonem berbeda.

Setelah menetapkan kata-kata kerabat dengan prosedur seperti yang dikemukakan di atas, maka dapat ditetapkan besarnya persentase dari kedua bahasa yang dibandingkan dengan teknik perhitungan persentase leksikostatistik, yaitu Menghitung 
presentase kekerabatan dengan cara menetapkan dan menghitung pasangan katakata kerabat yang sama dan mirip.

$$
\frac{\text { Jumlah kata yang sama }+ \text { jumlah kata yang mirip }}{\text { jumlah kata yang diteliti }} \times 100 \%
$$

Selanjutnya dapat ditentukan status hubungan kekerabatan antar bahasa tersebut pada rentanganklasifikasi sebagai berikut:

\section{Klasifikasi presentase kekerabatan}

Dialect of language

$81-100 \%$

Language of familly

$36-81 \%$

Families of stock

$12-36 \%$

Stock of microphilum

$04-12 \%$

Microphyla of esophyulum

$01-4 \%$

Mesophyla of acrophylum

$00-1 \%$

\section{HASIL DAN PEMBAHASAN}

Dari beberapa ekoleksikon yang berhubungan dengan pohon kelapa, terdapat lebih banyak perbedaan kosakata daripada persamaannya, hanya didapati 6 ekoleksikon kenyiuran yang sama atau mirip, seperti dibawah ini:

Tabel 1. Ekoleksikon kenyiuran yang sama atau mirip antara bahasa bali dan bahasa sasak

\begin{tabular}{|l|l|l|l|}
\hline No & \multicolumn{1}{|c|}{$\begin{array}{c}\text { Bahasa } \\
\text { Bali }\end{array}$} & \multicolumn{1}{|c|}{$\begin{array}{c}\text { Bahasa } \\
\text { Sasak }\end{array}$} & \multicolumn{1}{|c|}{ Makna } \\
\hline 1 & Busung & Busung & Janur Muda \\
\hline 2 & Kelabang & Kelabang & $\begin{array}{l}\text { Anyaman dari } \\
\text { janur tua }\end{array}$ \\
\hline 3. & Santen & Santen & Santan \\
\hline 4. & Usam & Usam & $\begin{array}{l}\text { Sisa perasan } \\
\text { parutan } \\
\text { buah kelapa }\end{array}$ \\
\hline 5. & Sambuk & Kombut & Serabut Kelapa \\
\hline 6. & Gobet & Gobet & $\begin{array}{l}\text { Alat pemarut } \\
\text { isi buah kelapa } \\
\text { tua }\end{array}$ \\
\hline
\end{tabular}

Selain itu, sebagai bahan acuan tambahan, maka akan digunakan data berdasarkan sebutan bilangan angka yang terdapat pada kedua bahasa ini seperti pada tabel berikut:

Tabel 2. Sebutan bilangan angka bahasa bali dan bahasa sasak

\begin{tabular}{|l|l|l|l|}
\hline No & \multicolumn{1}{|c|}{ Bahasa Bali } & $\begin{array}{c}\text { Bahasa } \\
\text { Sasak }\end{array}$ & \multicolumn{1}{|c|}{ Makna } \\
\hline 1 & Besik & Sekeq & Satu \\
\hline 2 & Dadua / dua & Due & Dua \\
\hline 3 & Telu & Telu & Tiga \\
\hline 4 & Papat & Empat & Empat \\
\hline 5 & Lima & Lima & Lima \\
\hline 6 & Nem & Enem & Enam \\
\hline 7 & Pitu & Pituq & Tujuh \\
\hline 8 & Kutus & Baluq & Delapan \\
\hline 9 & Sia & Siwaq & Sembilan \\
\hline 10 & Dasa & $\begin{array}{l}\text { Sepulu/ } \\
\text { Dasa }\end{array}$ & Sepuluh \\
\hline
\end{tabular}

Dari data diatas dapat dilihat bahwa terdapat sedikit perbedaan untuk penyebutan bilangan antara bahasa Bali dan Sasak. Misalnya pada pelafalan sebutan bilangan Sembilan, yaitu siya dalam bahasa Bali dan siwaq dalam bahasa Sasak. Perbedaannya terletak pada tengah kata yaitu adanya bunyi y dan w. Bunyi tersebut berbeda dari cara artikulasinya namun memiliki kedekatan bunyi karena keduanya merupakan bunyi konsonan semivokal. Selain itu kemiripan juga terdapat pada bilangan tujuh yaitu pitu dan pituq. Menurut Keraf (1991), bila dalam satu pasangan kata terdapat perbedaan satu fonem, tetapi dapat dijelaskan bahwa perbedaan itu terjadi karena pengaruh lingkungan yang dimasukinya, sedangkan dalam bahasa lain pengaruh lingkungan itu tidak mengubah fonemnya, maka pasangan itu dapat ditetapkan sebagai kata kerabat, asal segmennya cukup panjang.

Persentase kekerabatan kedua bahasa tersebut dilihat dari data yang digunakan pada penelitian ini adalah sebagai berikut:

Jumlah kosakata yang sama : 13

Jumlah kata yang mirip : :9

Jumlah kosakata yan beda : 32

$$
\text { persentase }=\frac{13+9}{32} \times 100 \%=68.75 \%
$$

Sehingga status kekerabatan bahasa Bali dan bahasa Sasak adalah language of family 


\section{PENUTUP}

\section{Kesimpulan}

Dari artikel ini, maka dapat disimpulkan bahwa bahasa Bali dan bahasa Sasak memang benar memiliki hubungan kekerabatan yang dapat dipengaruhi dari letak geografis nya yang berdekatan dianalisis dari kosakata yang berhubungan dengan kelapa dan tambahan data berupa bilangan angka.

\section{DAFTAR PUSTAKA}

[1] Crowley, Terry. 1997.An Introduction to Historical Linguistics. Oxford: Oxford University Press.

[2] Keraf, Gorys. 1991. Penetapan Negeri Asal Bahasa-Bahasa Austronesia. Jakarta: Pidato pada Pengukuhan Jabatan Guru Besar Tetap pada Fakultas Indonesia.

[3] Moleong, Lexy J. 2006. Metodologi Penelitian Kualitatif. [Edisi Revisi] Bandung: Rosdakarya.

[4] Panggabean, Himpun. 1994. Telaah Bahasa-Bahasa Batak Dari Segi Leksikostatistik. Bandung: Program Pascasarjana Universitas Padjadjaran. Bandung.

[5] Sugondo, D.(Kepala Pusat Bahasa 2010)."Bahasa Daerah di Indonesia". (online) http://bahasanusantara.blogspot.com. diakses kamis 3 februari 2011.Sumber kompas.com 